\section{A presumed Leichhardt geological specimen in the Queensland Museum}

Memoirs of the Queensland Museum - Nature 59: 186. 2015:The number of geological specimens collected by Ludwig Leichhardt during his extensive travels, in Australia, is not known. However, in July 1844 prior to departing from Sydney on his ill-fated expedition to cross the continent from east to west (Erdos 1967) he dispatched 288 mineral and rock specimens to the Museum d'Histoire Nationale in Paris and a collection of fossils to Richard Owen at the Royal College of Surgeons in London (Darragh 2013). Nonetheless, as Darragh acknowledged, other specimens may lie unrecognised in Australian geological collections, and especially those of the Australian Museum, which in Leichhardt's time was the only institution in the Colony of New South Wales functioning as a museum.

The presence, in the Queensland Museum, of an axial sandstone cast (QMF3275) of Leptophloeum australe (McCoy) Walton, labelled 'Leichhardt Clarke River,' (Clifford 1996 1B) and presumably collected during Leichhardt's Expedition from Moreton Bay to Port Essington, was overlooked by Darragh and is therefore noteworthy. Subsequent to 1996 the label has become detached from the specimen and neither it nor the negative of Fig. 1 has been located and so both may be assumed lost. However, there are no reasons to doubt the wording of the inscription for it is remembered clearly by both the present authors. Regrettably, it has not been possible to determine either the donor of the specimen or the date it was incorporated into the Museum collection. The earliest Register in which reference is made to the specimen is dated 1948 and the entry provides no information additional to that given on the label.

Neither the exact date nor location at which the cast was collected is known but in April 1844 the Expedition was in the vicinity of $145.5 \mathrm{E}, 19.4 \mathrm{~S}$ close to the junction of the Clarke and Burdekin Rivers (Leichhardt 1847 p. 225), about $200 \mathrm{~km}$ west of Townsville. Thereabouts, shallow water Mississippian sediments of both the Venetia and Ruxton Formations outcrop. Casts of Leptophloeum australe have been reported from both Formations (Henderson \& Withnall 2013) and are sometimes exposed on the weathered surfaces of Ruxton Formation sandstones. (Cook pers. obs). As such sediments do not occur elsewhere along the expedition's route it is reasonable to assume the specimen was collected at the above cited locality.

By September the Expedition was in difficulty and on $7^{\text {th }}$ October 1844 Leichhardt parted, 'with a small collection of rocks made by Mr. Gilbert,' so as to ease the burden

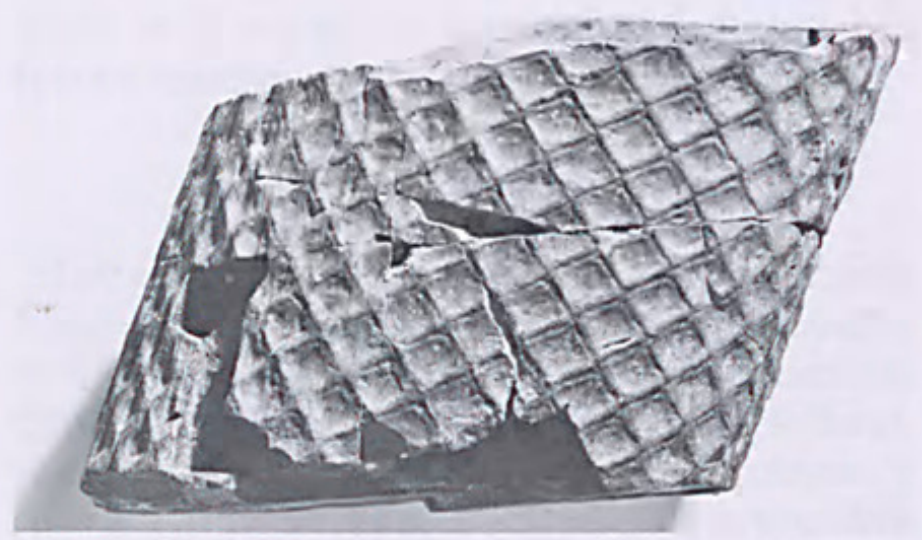

FIG. 1. Specimen of Leptophloeum australe labelled Leichhardt Clarke River (QMF3275). of a packhorse (Leichhardt 1847, p. 428). Disaster struck again, a fortnight later, when three of the pack-horses, each carrying specimens, drowned after slipping into the Roper River (Leichhardt 1847, p. 445).

It is clear Leichhardt did not dispose of all his geological specimens when he discarded the Gilbert collection because the published account of the expedition includes a description of Cyathophyllum leichhardti, a fossil coral, collected some months earlier, near the Burdekin River, far to the south. This specimen was described by Reverend W.B. Clarke (Leichhardt 1847, p.212), a geologist of Parramatta, and was almost certainly lost on 22nd September 1882, when fire destroyed the Garden Palace, Sydney, where the palaeontological specimens of the recently deceased W.B. Clarke' were stored (Gilbert 1986, p. 107). The name, Cyathophyllum leichhardti, was not synonymised by Zhen \& Jell (1996), in their work on Devonian corals and so its status will remain unclear unless the original specimen is located.

Unfortunately, the history of the cast, prior to its acquisition by the Queensland Museum, is not known. However, it is probable that before setting out from the Darling Downs, in February 1848 on what was to his final Expedition Leichhardt left, for safe keeping, the specimen together with a chest and other items, (David Parkhill pers. comm. 15 May 2015), with Thomas Alford, a hotel keeper, on the Darling Downs. The two men were acquainted, as Leichhardt had stayed at 'Alford's House of Accommodation' in June 1842 when en route to Brisbane (Darragh \& Fensham 2013, p. 239).

Throughout it has been accepted that the cast of Leptophloeum australe and the specimen of Cyathophyllum leichliardti were collected by Leichhardt (Fig. 1). However, the possibility that he rescued them from the 'small collection of rocks' made by the zoologist-ornithologist John Gilbert cannot be discounted, because his death did not occur until some weeks after the Expedition had left the Clarke River area (Leichhardt 1847) and so the name on the Queensland Museum label may refer to the Expedition rather than its leader.

The authors thank their Museum colleagues Megan Lloyd, who searched the Museum Registers for entries relevant to Leichhardt's specimen, and David Parkhill who is studying the history of the wooden chest, left with Alford, for safe keeping.

\section{Literature Cited}

Clifford, H.T. 1996. Geometrical study of a cast of Leptophloeum australe (McCoy) Walton from Queensland. Memoirs of the Queensland Museum 39: 227-230.

Darragh, T.A. 2013. Leichhardt as a geologist. Memoirs of the Queensland Museum-Culture 7: 575-597.

Darragh, T.A. \& Fensham, R.J. 2013. The Leichhardt Diaries: Early travels in Australia during 1842-1844. Memoirs of the Queensland Musetum - Culture 7: 1-540.

Erdos, R. 1967. Leichhardt, Friedrich Wilhelm Ludwig. In Kemp, J. (Ed.) Australian Dictionary of Biography 2: 102-104.

Gilbert, L.A. 1986. The Royal Botanic Gardens, Sydney; a history, 18161985. (Melbourne: Oxford University Press).

Henderson, R.A. \& Withnall, W. 2013. Mossman Orogen, Broken River Province. In Jell, P.A. (ed.) Geology of Queensland, Pp. 250-279.

Leichhardt, L. 1847. Journal of an overland expedition in Australia from Moreton Bay to Port Essington, a distance of upwards of 3000 miles, during the years 1844-1845. (London: T. \& W. Boone).

Zhen, Y.Y. \& Jell, I.S. 1996. Middle Devonian rugose corals from the Fanning River Group, north Queensland. Palaeontographica A 242: $15-89$.

H. Trevor Clifford \& Alex G. Cook, Queensland Museum, PO Box 3300 South Brisbane QId 4101 P 186 First published online 21 September 2015 http://dx.doi.org/10.17082/j.2204-1478.59.2015.2015-05 


\section{$2 \mathrm{BHL}$ Biodiversity Heritage Library}

Clifford, H. T. and Cook, Alex G. 2015. "A presumed Leichhardt geological specimen in the Queensland Museum." Memoirs of the Queensland Museum 59, 186-186. https://doi.org/10.17082/j.2204-1478.59.2015.2015-05.

View This Item Online: https://www.biodiversitylibrary.org/item/282460

DOI: https://doi.org/10.17082/j.2204-1478.59.2015.2015-05

Permalink: https://www.biodiversitylibrary.org/partpdf/306758

\section{Holding Institution}

Queensland Museum

\section{Sponsored by}

Atlas of Living Australia

\section{Copyright \& Reuse}

Copyright Status: In copyright. Digitized with the permission of the rights holder.

Rights Holder: Queensland Museum

License: http://creativecommons.org/licenses/by-nc-sa/4.0/

Rights: http://biodiversitylibrary.org/permissions

This document was created from content at the Biodiversity Heritage Library, the world's largest open access digital library for biodiversity literature and archives. Visit BHL at https://www.biodiversitylibrary.org. 